\title{
Benchmarking Teaching Methods Using Kahoot in Business Feasibility Study Courses at Campus II Payakumbuh UNAND
}

\author{
Winny Alna Marlina ${ }^{1}$, Susiana ${ }^{2}$, Erizal $^{3}$ \\ \{winnyalnamarlina@eb.unand.ac.id ${ }^{1}$ \} \\ 1,2,3 Department of Management, Universitas Andalas, Padang, Indonesia
}

\begin{abstract}
Business Feasibility Study is a compulsory subject in the Faculty of Economics' Management which 45\% student taught hard to learning and 55\% feel bored. This research aims to benchmark teaching methods using Kahoot for two students a different year between students of 2015 and 2016. Benefits of research to find business Feasibility Study is a compulsory subject in the Faculty of Economics' Management which $45 \%$ student taught hard to learning and $55 \%$ feel bored. This research aims to benchmark teaching methods using Kahoot for two students a different year between students of 2015 and 2016. Benefits of research to find learning methods by utilizing technology in the teaching and learning process. $100 \%$ of the participants have none of Kahoot experiences before, but $95 \%$ of students in two classes possess a smartphone that can connect to the university Wi-Fi and they are familiar with interactive technology. The results after participating in the Business Feasibility Study course, the distribution of the final grades of students increased compared to the distribution of the previous learning methods by utilizing technology in the teaching and learning process. $100 \%$ of the participants have none of Kahoot experiences before, but $95 \%$ of students in two classes possess a smartphone that can connect to the university Wi-Fi and they are familiar with interactive technology. The results after participating in the Business Feasibility Study course, the distribution of the final grades of students increased compared to the distribution of the previous year.
\end{abstract}

Keywords: Kahoot, teaching methods, feasibility study.

\section{Introduction}

Business Feasibility Study is a compulsory subject in the Faculty of Economics' Management Curriculum taught in semester 6. To take part in the Business Feasibility Study course, it is required that students pass a minimum of $\mathrm{C}$ for Financial Management courses I (courses in semester 3) and Business Budgeting (courses in semester 4). The purpose of the Business Feasibility Study course, students are required to find creative and innovative business ideas and then make the business in a report and study it in terms of existing aspects to determine whether the business is feasible or not. By taking part in the Business Feasibility Study course students are trained to bring their business ideas to their classmates to improve communication skills, sharpen their analysis and teamwork. The learning methods that have been applied so far are the Student Center Learning (SCL) and Research-based learning (RBL) but have not applied Kahoot in the learning process. 
One of the games that appeared on the learning platform used in educational institutions was Kahoot [1]. "Kahoot!" Is an educational website that was initially initiated by Johan Brand, Jamie Brooker, and Morten Versvik in a joint project with Norwegian University of Technology and Science in March 2013. In September 2013, Kahoot! a tool for using technology to administer quizzes, discussions or surveys. It is a game-based classroom response system played by the whole class in real time. Multiple-choice questions are projected on the screen. Students answer the questions with their smartphones, tablets or computers. Utilizing Kahoot helps support student metacognition by providing immediate feedback. Kahoot also offers the opportunity to not only assess students' conceptual understandings but also support the construction of new knowledge and understanding through further explanation during or after the game. A study in two different business courses carried out by Plump and LaRosa [2] addressing students' experience using Kahoot yielded a result of an $88.7 \%$ positive response rate. Overall, utilizing Kahoot was a positive experience that resulted in our classes with activities and focus and ways for all students, not just being extroverted students, to participate and contribute to the learning environment.

According to Jacobsen et.al [3] Learning to teach is complex and multifaceted that requires many different kinds of knowledge. Among these are the following: Content knowledge, Pedagogical knowledge, and Teaching skills. Research in the field of educational design has shown that game-based learning is one of the effective tools in teaching specially to maintain learning motivation for sustainability [4].

Gamification is not a very new concept. It is defined as the use of game elements and game design techniques in a non-game context. It is used in various contexts and almost all levels of education. In higher education, games have been found to be beneficial for academic achievement, motivation and classroom dynamics [5].

The benefits gained from the use of new technologies will depend on the extent to which they are used in ways compatible with the learning process [6]. In applying SCL and RBL the distribution of 2015 BP Student values varies with the average value still below the standard, which is below 50. In this case, it shows that students cannot absorb 100\% courses. Only 5\% of students have values above 70 so in this case, the business study courses are still far from the expected results. For the top 10 highest scores as in Table 1. where the highest score is only 86.

Table 1. Top-Rated Students Who Follow Business Feasibility Studies

\begin{tabular}{llc}
\hline No & Name & Grade \\
\hline 1 & Suci Anugrah Esa T & 86 \\
2 & Zaki Al Huda & 84 \\
3 & Vika & 78 \\
4 & Eko Saputra Sidabutar & 76 \\
5 & Lira Fatma Sucitra & 73 \\
6 & Sindy Azhari & 72 \\
7 & Nurchaira Putri & 71 \\
8 & Ranti Dinaren & 71 \\
9 & Hafizatulhusna & 69 \\
10 & Ega Okta Irza & 68 \\
\hline
\end{tabular}


Problems in achieving student learning outcomes because the 55\% business feasibility study course is considered heavy by students and $45 \%$ is boring as shown in Figure 1.

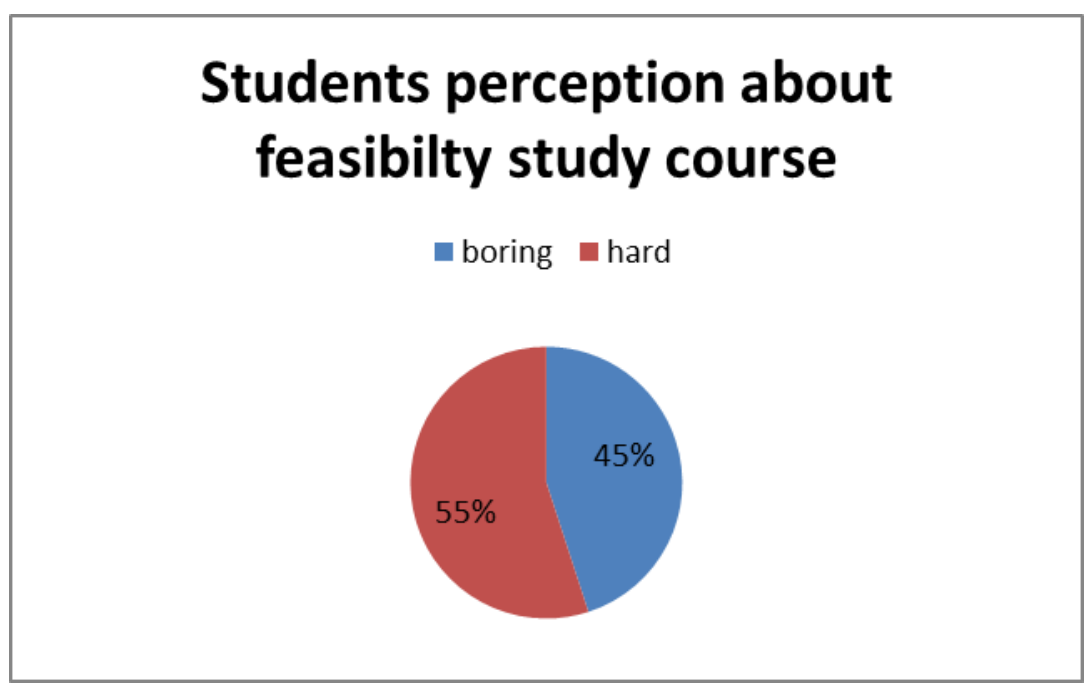

Figure 1. Student Opinions on Business Feasibility Studies

Because the business feasibility study course is considered boring and heavy so it is necessary to change the learning method by using the Kahoot Application in learning media. The method used is still conventional and not creative, as well as passive students and the application of the Kahoot application has not been implemented to develop the mind-set of students so that degrees are more enjoyable.

The purpose of the study was to determine the results of the application of the Kahoot application to the learning process of students in the feasibility study course and to compare the results of grades for the class of 2015 with 2016 in the course of business feasibility studies. Benefits of research to find learning methods by utilizing technology in the teaching and learning process.

\section{Methodology}

The subject of the research on the development of the teaching method technology using the Kahoot application is the Student Management Department Campus II Payakumbuh Andalas University class of 2016 compared to the grade of 2015.

Participants have a total of 75 four-year students taking part in the business feasible study subject. $100 \%$ of the participants have none of Kahoot experiences before, but $95 \%$ of students in two classes possess a smartphone that can connect to the university Wi-Fi and they are familiar with interactive technology. The 2015 class did not use Kahoot in the temporary business feasibility study in 2016 class using Kahoot.

In this study, in obtaining the data that is in the form of numbers - numbers that can be processed by statistical methods. And the scope of time in this study is in the form of a oneshot. One-shot itself means that data is taken once in an event without any subsequent data 
retrieval. Time of study for 6 months even semester 2018/2019 starting from January 2019 to May 2019.

Table 2. Duration of Action Using the Kahoot Application

\begin{tabular}{ll}
\hline Week of Action & Duration \\
\hline Legal aspects & 30 minutes \\
Market and marketing aspects & 30 minutes \\
Technical and technological aspects & 30 minutes \\
Quiz & 60 minutes \\
Organization and management aspects & 30 minutes \\
Environmental aspects & 30 minutes \\
Financial aspects & 30 minutes \\
Total & 240 minutes \\
\hline
\end{tabular}

The place of research at Campus II Payakumbuh Andalas University. Campus Location II Payakumbuh Andalas University on J1. Rasuna Said, City of Payakumbuh.

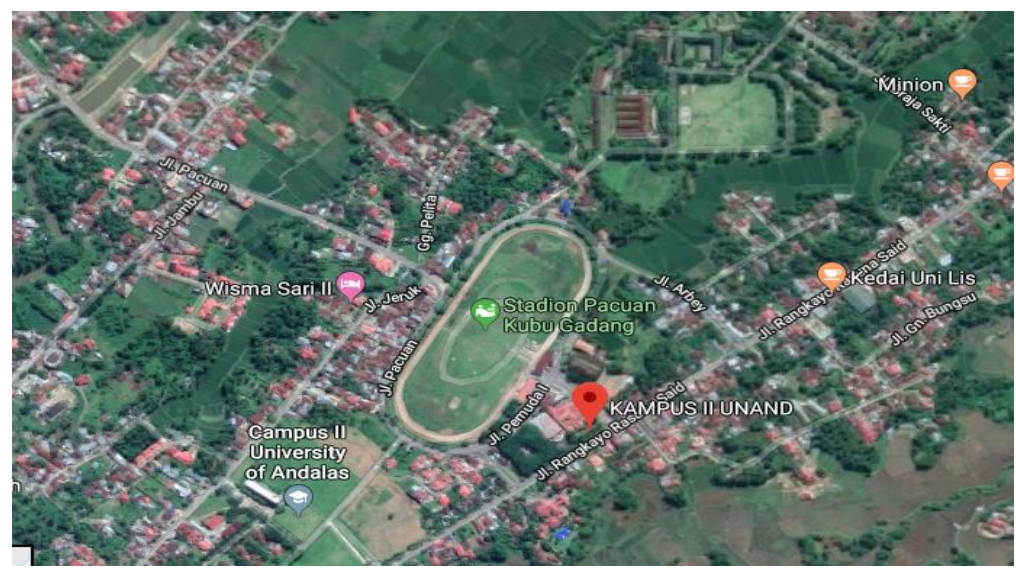

Figure 2. Payakumbuh UNAND Campus II Location (Source: Google Maps, 2019)

The type of research used is the research and development method (Research and Development). Research and Development is a research method used to produce certain products, and test the effectiveness of these products. The research step in the learning method by using quantitative data types is to explain the results of product development made in the form of an evaluation tool using the Kahoot application. A qualitative research approach is relevant to the study because it is not easily distinguished from the context in which it is observed [7]. The type of test used is in the form of a quiz using the Kahoot application.

Kahoot! games, including suspense music, where used mobile devices students (smartphones, tablets, and laptops) to join the games and answer questions, and responses to choices were visualized [8] (illustrated in Figure 3). 


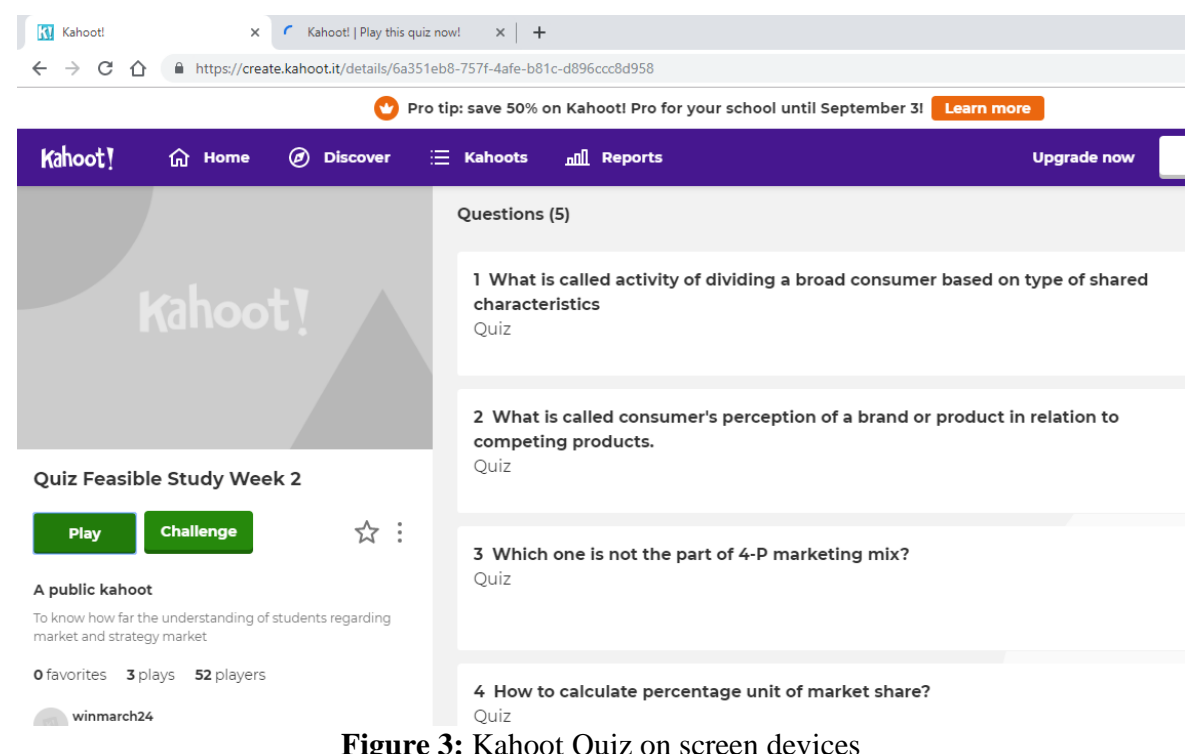

Figure 3: Kahoot Quiz on screen devices

The instrument used was a Likert-scale based survey, in which students were perceptions about the use of Kahoot across the course and how the technology affected their class engagement. The questionnaire consists of items that range from strongly disagree (1) to strongly agree (5). It was designed by the researcher and delivered to the students directly. At the end of the survey, there were open-ended questions for students to give opinions on the benefits and drawbacks of Kahoot. They were also welcomed to other comments anonymously.

During the semester, each class was given 30 minutes Kahoot sessions, with a variety of questions per session, using personal devices connected to university Wi-Fi to respond. Questions consist of 50 to 100 questions and students logged into kahoot.it, entered the PIN and the teacher started to show questions. After each question, the teacher required the groups to click on the correct answer. Once a question started, a timer appeared on the screen. When the time was up, the correct answer was shown, the student responses were displayed as a bar graph with the distribution of answers

\section{Results and Discussion}

The demographic gender rate for the student year 2016 is $31 \%$ male, $69 \%$ female and for the student year 2015 is $30 \%$ male, $70 \%$ female (Figure 4 and Figure 5) 


\section{Student 2016}

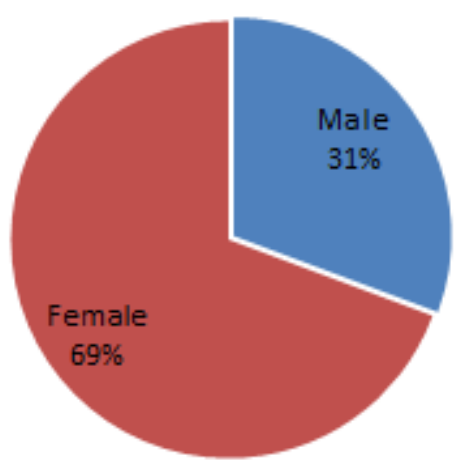

Figure 4. The 2016 Student Force characteristics in the Business Feasibility Study Course

\section{Student 2015}

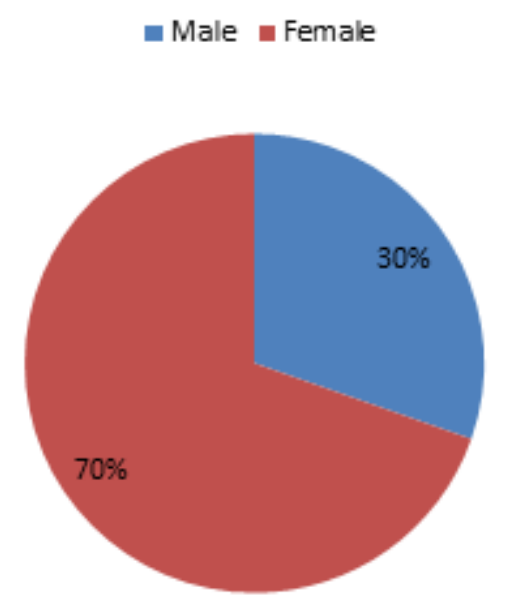

Figure 5. The 2015 Student Force characteristics in the Business Feasibility Study Course

In a survey conducted on April 23, 2019, the Department of Campus Management II Payakumbuh, Andalas University was very fond of learning by using the Kahoot application, especially for business feasibility study courses as shown in Figure 6. 


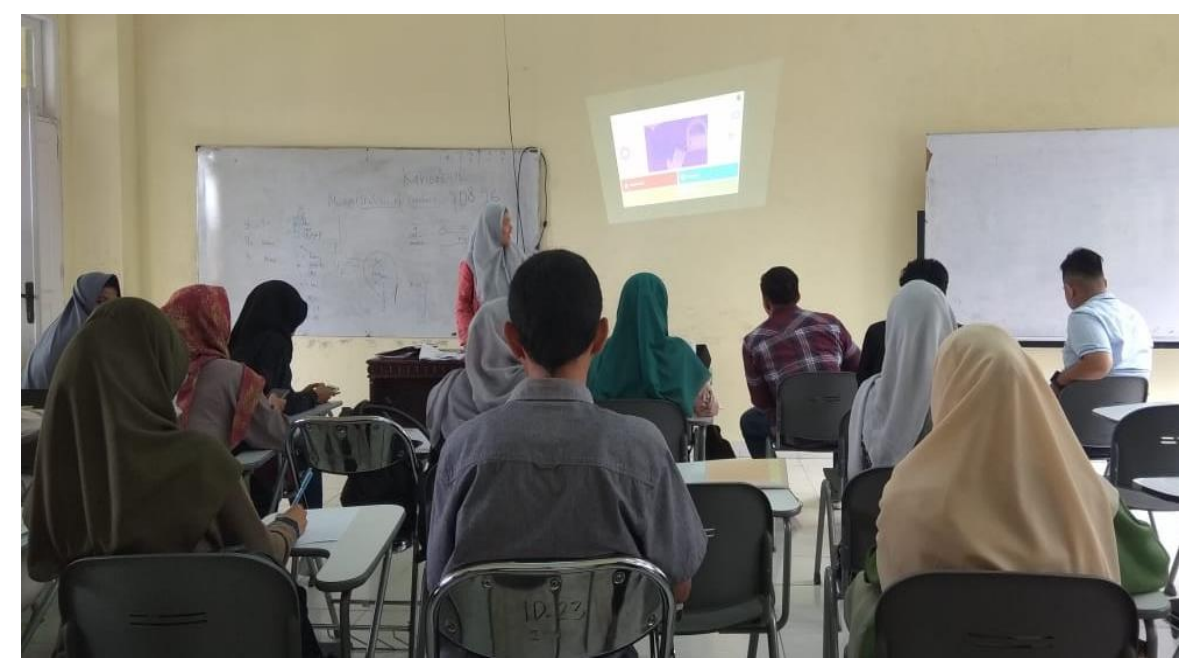

Figure 6. Student of UNAND Campus II Management Department

In implementing the Kahoot application as a learning media, $72 \%$ of students are satisfied as shown in Figure 7.

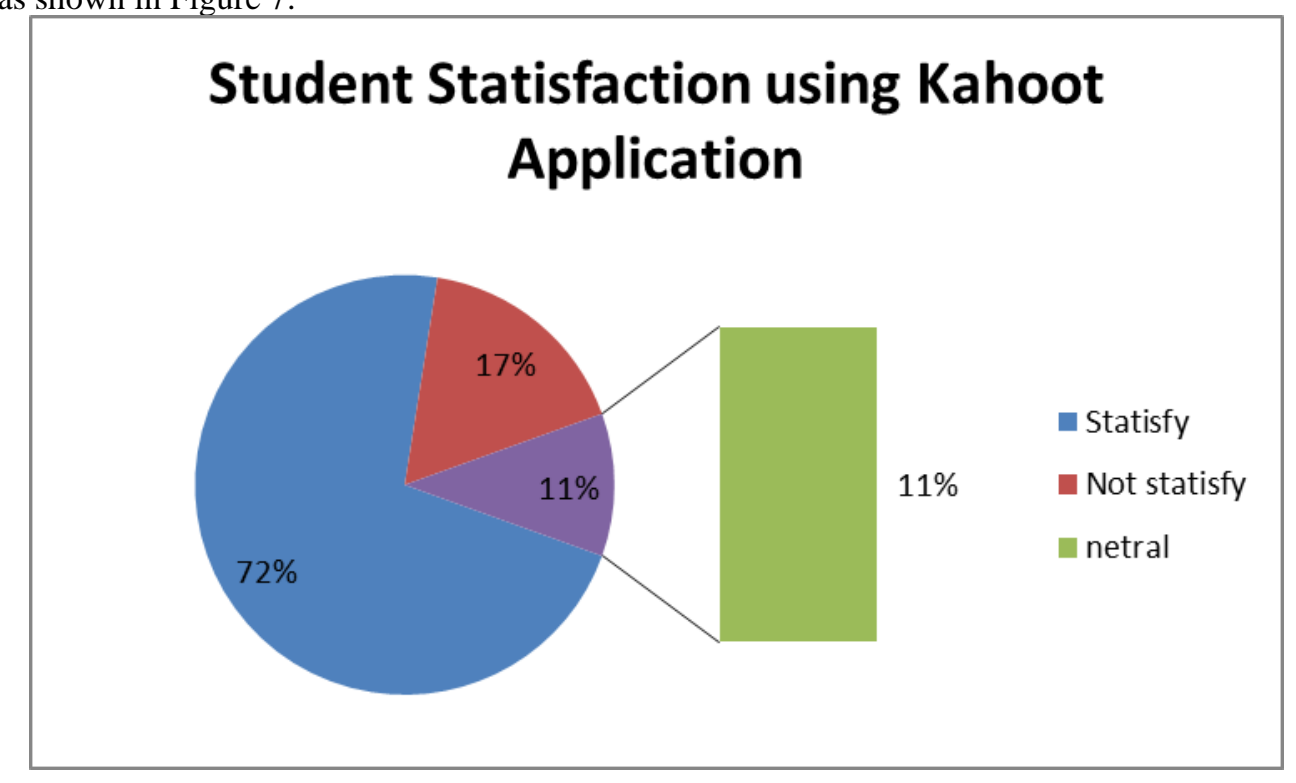

Figure 7. Student Satisfaction in Using the Kahoot Application in learning

The results after participating in the Business Feasibility Study course, the distribution of the final grades of students increased compared to the distribution of the previous year. 


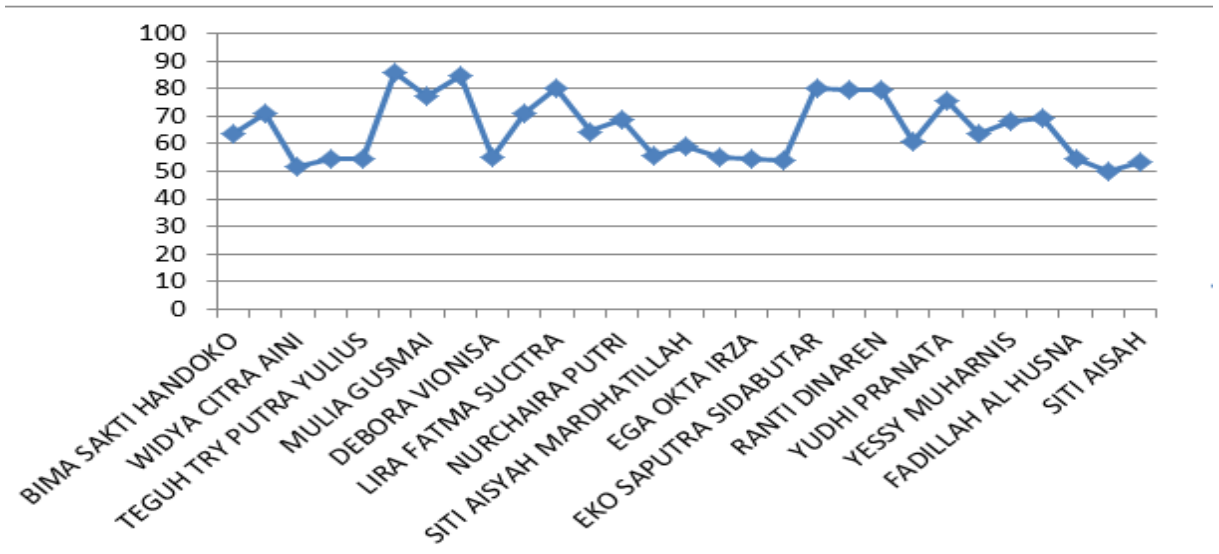

Figure 8. Distribution of Final Values from Management Students of 2015 Campus II UNAND

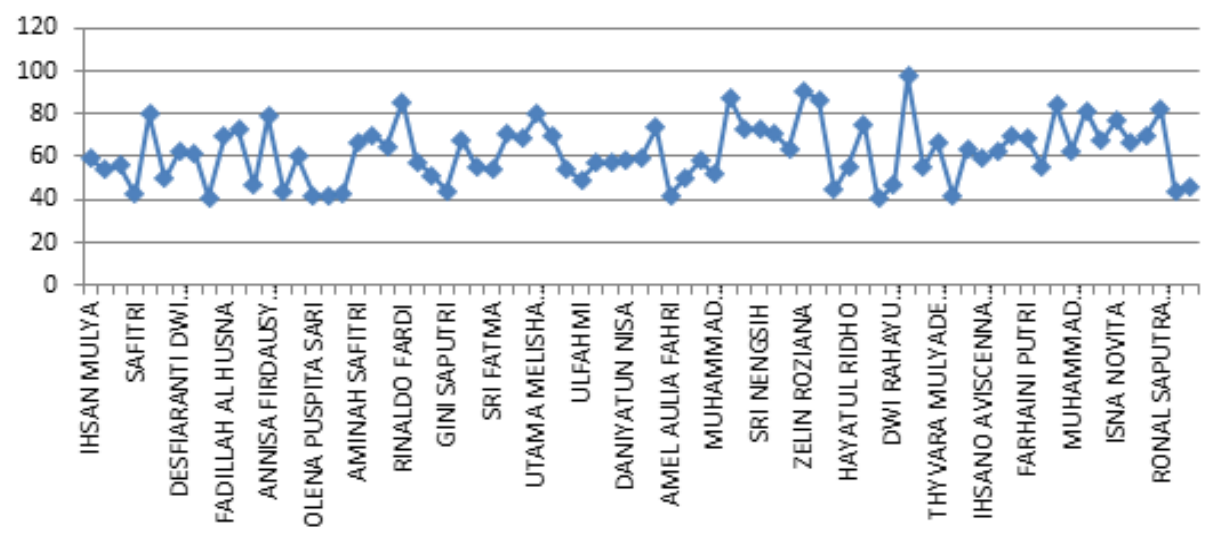

Figure 9. Distribution of Final Values from Management Students of 2016 Campus II UNAND

The value distribution for the business feasibility study course increased from 2015 to 2016. For the 2016 batch Management majors used the Kahoot application in learning where the percentage value increases as in Table 3.

Table 3. Percentage of increase in Student Values from 2015 to 2016

\begin{tabular}{cc}
\hline Grades & \% Increase in Value \\
\hline A & $64 \%$ \\
A- & $100 \%$ \\
B+ & $0 \%$ \\
B & $67 \%$ \\
B- & $33 \%$ \\
C+ & $18 \%$ \\
C & $9 \%$ \\
D & 0 \\
E & 0 \\
\hline
\end{tabular}


In the use of the Kahoot Application, students really like it because it is cool but have the disadvantage of having to have a stable internet signal because when quizzes and internet networks are problematic the Quiz must start from the beginning.

\section{Conclusions}

In applying the Kahoot application in the learning method in the Business Feasibility Study course at Campus II students, Andalas University has a value increase from the previous year namely A value of $64 \%$, A-100\%, B value $67 \%$, B-value of $33 \%, \mathrm{C}+18 \%$ and $\mathrm{C}$ value $9 \%$. The weakness of the application is that it must have a stable internet network so that there are no obstacles in learning activities. It is necessary to apply the Kahoot application to other subjects

\section{Acknowledgements}

Thank you for students who participated for survey and thank for LPPM Andalas University to support this research.

\section{References}

[1] arren H. Iwamoto et al., Analyzing The Efficacy Of The Testing Effect Using Kahoott On Stident Performance, Turkish Online Journal Of Distance Education-TOJDE, 2017, Hal 82.

[2] Plump, C. M., \& LaRosa, J. Using Kahootin the Classroom to Create Engagement and Active Learning: A Game-Based Technology Solution for eLearning Novices. Management Teaching Review, 2(2), 151-158. (2017).

[3] Jacobsen, David, et al,. Methods for teaching promoting students learning in K-12 Classrooms. Eight Edition, Pearson, (2008).

[4] Huang, W. H. Evaluating learners' motivational and cognitive processing in an online game-based learning environment. Computers in Human Behavior, 27(2), 694- 704. (2011)

[5] Sharples, M. The design of personal mobile technologies for lifelong learning. Computer Education, 34(3-4), 177-193. (2000).

[6] Clark, R., \& Mayer, R. eLearning and the science of instruction: Proven guidelines for consumers and designers of multimedia learning. Pfeiffer. (2008).

[7] Yin, R. K. Case study research: Design and methods. Sage publication.

[8] Licorish, Sherlock, et al, "Go Kahoot!" Enriching Classroom Engagement, Motivation and Learning Experience with Games, New Zealand University of Otago, Dunedin. Proceedings of the 25th International Conference on Computers in Education. New Zealand: Asia-Pacific Society for Computers in Education. (2017). 